\title{
Management System for the Development of Industrial Social Relations of a New Technological Order
}

\section{Valery Vladimirovich Glushchenko}

\author{
Doctor of Technical Sciences, Associate Professor, Professor of the Project Activity Center, \\ Moscow Polytechnic University, Moscow, Russia \\ *Corresponding author details: Dr. Valery Vladimirovich Glushchenko; \\ glu-valery@yandex.ru
}

\begin{abstract}
the subject of the article is the mechanism of development of production institutions of a new technological order (way); the object of the study is the institutional relations of a new technological order; the purpose of the work is to increase the efficiency of the processes of development of institutions of a new technological order; to achieve this goal, the following tasks are solved: a systematic analysis of institutional relations for the entire period of technological development; description of the mechanism of development of production institutions of a new technological order; description of the functions of mental conflicts in the process of forming a new technological order; research of the functions of competition of scientific and pedagogical workers in the mechanism of development of industrial relations in the formation of a new technological order; scientific methods in the article are synthesis, historical analysis, logical analysis, forecast, expert assessments, monitoring; the scientific novelty of the article is determined by: the results of a systematic analysis of the mechanism of development of industrial relations during the formation of a new technological order; research of the functions of mental conflicts and competitions of scientific and pedagogical workers.
\end{abstract}

Keywords: system; mechanism; development; socio-industrial institute; technological order; competitions; functions; diagnostics; mental conflicts; assessment; effectiveness; conflict management; damage

\section{INTRODUCTION}

The relevance of the article is related to the development of socio-industrial institutions of the sixth technological order in the process of overcoming the global crisis. The relevance of the article is further increased due to the fact that during the development of a new technological order, the number of mental conflicts increases. At the same time, the risks and damages from mental conflicts for the innovation system are sharply increasing.

The hypothesis of the article is the assumption that the study of the functions of competitions and mental conflicts will increase the effectiveness of the mechanism for the formation of socio-industrial institutions of the sixth technological order.

The purpose of the work is to increase the efficiency of the processes of development of institutions of a new technological order.

To achieve this goal, the following tasks are solved:

- a systematic analysis of institutional relations for the entire period of technological development;

- description of the mechanism of development of production institutions of a new technological order;

- description of the functions of mental conflicts in the process of forming a new technological order;

- research of the functions of competition of scientific and pedagogical workers in the mechanism of development of industrial relations in the formation of a new technological order
The object of the study is the institutional relations of a new technological order.

The subject of the article is the mechanism of development of production institutions of a new technological order (way).

In the process of analyzing the literary sources in the Elibrary on the topic of the article, the following was revealed. Methods of managing large systems are studied [1, p. 6-11]. Models of interaction of structural parts of a complex system are studied [2, pp. 411-418]. Methods of presenting information about large systems are being developed [3, pp. 117-158].

The institutional approach is recognized as important for ensuring the innovative development of complex systems [4, pp. 130-133]. They study the institutional factors of a favorable business environment and the national innovation system [5, p. 126-132; 6, p.5-18]. Studies show that the global crisis is associated with the disharmony of the institutional environment and the technological basis of the economy [7, p.12-40]. The point of view is expressed that the heterogeneity of the globalization process can be a source of conflicts [8, p. 44-61]. Overcoming labor conflicts in the modern economy plays an important role [9, pp. 51-58].

Arguments are given in favor of the fact that the change of institutions during the formation of the sixth technological order can be a source of mental conflicts [10, p.12-26]. 
The substantiation is given that competitions of scientific and pedagogical workers can be a tool for accelerating the development of the sixth technological order $[11$, p. 27 40]. Researchers are interested in the lives and destinies of famous scientists who have become victims of conflicts [12, p. 82-95; 13, p. 3-14]. A scientist at the University of Cambridge, R. E. Fisher, examines the human qualities of famous scientists [14, pp. 82-83]. Researchers draw parallels between conflicts in the scientific environment of different countries [15]. This may indicate that such conflicts occur in the scientific environment in different countries.

The development of new scientific directions in the process of formation of the sixth technological order increases interest in the process of development of cybernetics in the 20 th century. The interrelation of the process of cybernetics development and the fate of scientists in the twentieth century is studied [16, p. 108-121].

Due to the rapid development of science of the sixth technological order, the relevance of risk research in this area is growing [17, p.113-123].

They note the involvement of ideology in the process of science development and conflicts in the scientific environment [18, p. 50-53].

It is noted that the age limit in relation to scientists may be a factor in reducing the quality of scientific research [19, pp. 550-553]. In addition, the introduction of such a qualification may contradict the provisions of the Universal Declaration of Human Rights on: equality of all people; prohibition of discrimination against people on any basis. Additionally, this can generate a conflict between generations of scientists and innovators.

The researchers note that conflict resolution in organizations is within the scope of managers ' activities. At the same time, the very concept of conflict is still debatable [20, p. 368-375; 21, p. 172-177; 22, pp. 47-72].

The analysis shows that the development of innovative activity affects the value of the innovative monetary multiplier in the economy and the stability of the national currency [23, pp. 77-88].

The development of the sixth technological order may consist of the process of developing a number of technological platforms [24, pp. 201-212].

The process of formation of socio-professional institutions of the sixth technological order is also influenced by the appearance of people with clip thinking [25, p. 109-111].
At the same time, the process of strategic planning of the transition of enterprises to the sixth technological order is carried out [26, p.30-38].

Research shows that the structure of the technological structure includes: the technological basis of organizations; socio-industrial, professional institutions; organizational structures and management methods; methods of scientific research and education [22, pp.65-70;27, pp. 54-63].

The analysis showed that there is currently no methodology for managing the process of forming socio-professional institutions.

\section{METHOD}

Let's call the set of elements a management system for the development of production institutions of a new technological order. These elements are designed to have a controlling influence on the development of industrial relations. These relations should correspond to the essence and content of the technologies of the new technological order.

The mechanism of development of socio-professional institutions of the sixth technological order will be called a set of methods and forms of management of the process of development of such institutions.

The forms and methods of management of the development of socio-industrial institutions include: planning, organization, motivation and control of this process; organizational culture; sociology and psychology of work, mental conflicts; competitions of scientific and pedagogical workers and others. The lack of a methodology for the development of institutions can slow down the development of such institutions.

Mental conflicts during the formation of the sixth technological order can slow down the development of the country. This will lead to a decrease in the country's competitiveness. Thus, the conflict described in [12, p. 82$95 ; 13$, p. $3-14 ; 14$, p. $82-83 ; 15 ; 16$, p. 108-121] presumably led to a catastrophic lag of the state in the field of computer technology. This probably significantly increased the risk of fragmentation of the state.

The methodology for studying the transformations of elements and institutions during the transition from one technological structure to another was proposed in [27, p. 54-63; 26, p. 36-38; 10, p.12-26]. The study of the types of new socio-economic institutions in the process of developing a series of technological orders is described in Table No. 1. 
TABLE 1: Analysis of the process of transformation of socio-economic institutions during the change of technological orders (beginning)

\begin{tabular}{|c|c|c|c|}
\hline $\begin{array}{c}\text { № } \\
\Pi / \Pi\end{array}$ & $\begin{array}{l}\text { Institutes of technological structure } \\
\text { Name, number, time period of } \\
\text { technological structure }\end{array}$ & $\begin{array}{l}\text { Type of state, } \\
\text { State system, } \\
\text { World order }\end{array}$ & Science and education \\
\hline (1) & (2) & (3) & (4) \\
\hline 1 & $\begin{array}{l}\text { Horse traction; "1" (the first) } \\
\text { technological order (way), } \\
2000 \text { BC. - IX century AD; }\end{array}$ & $\begin{array}{l}\text { Communities, } \\
\text { community-tribal, } \\
\text { regional relations }\end{array}$ & $\begin{array}{l}\text { Scientific research and } \\
\text { education in monasteries and } \\
\text { schools of famous } \\
\text { philosophers, scientists }\end{array}$ \\
\hline 2 & $\begin{array}{l}\text { Windmill, a water mill; } \\
\text { "2nd" technological order, } \\
\text { IX century-1770; }\end{array}$ & $\begin{array}{l}\text { Principalities, } \\
\text { regional geopolitical relations }\end{array}$ & $\begin{array}{c}\text { Research and education at } \\
\text { universities }\end{array}$ \\
\hline 3 & $\begin{array}{l}\text { Textile machines, the } \\
\text { third technological order, } \\
\text { 1770-1830; }\end{array}$ & $\begin{array}{l}\text { Empires, } \\
\text { monarchies, } \\
\text { imperialism }\end{array}$ & $\begin{array}{l}\text { Scientific research and } \\
\text { education in academies of } \\
\text { sciences, universities, } \\
\text { factories and manufactories }\end{array}$ \\
\hline 4 & $\begin{array}{c}\text { Steam engine, } \\
\text { The fourth technological mode, } \\
\text { 1830-1880; }\end{array}$ & $\begin{array}{l}\text { Empires, } \\
\text { monarchies, } \\
\text { imperialism }\end{array}$ & $\begin{array}{c}\text { Scientific research and } \\
\text { education in the academies of } \\
\text { Sciences, } \\
\text { universities, factories and } \\
\text { manufactories }\end{array}$ \\
\hline 5 & $\begin{array}{l}\text { Internal combustion engine and } \\
\text { electric motor; } \\
\text { the fifth technological order, } \\
\text { 1880-1930; }\end{array}$ & $\begin{array}{l}\text { National states, } \\
\text { republics, } \\
\text { currency blocks }\end{array}$ & $\begin{array}{l}\text { Scientific research and } \\
\text { education in the academies of } \\
\text { Sciences, } \\
\text { universities, technical schools, } \\
\text { technological institutes }\end{array}$ \\
\hline 6 & $\begin{array}{l}\text { Electronic computer, genetics; } \\
\text { the sixth technological order, } \\
\text { 1930-1970; }\end{array}$ & $\begin{array}{c}\text { States, } \\
\text { military-political blocs, } \\
\text { bipolar world, } \\
\text { UN }\end{array}$ & $\begin{array}{l}\text { Scientific research and } \\
\text { education in the academies of } \\
\text { Sciences, } \\
\text { universities, technological } \\
\text { institutes, laboratories of } \\
\text { corporations }\end{array}$ \\
\hline 7 & $\begin{array}{l}\text { Microelectronics, the } \\
\text { seventh technological order, } \\
\text { 1970-2010; }\end{array}$ & $\begin{array}{c}\text { States, } \\
\text { trade and economic blocs, } \\
\text { unipolar world, } \\
\text { UN }\end{array}$ & $\begin{array}{l}\text { Scientific research and } \\
\text { education in } \\
\text { technological institutes, } \\
\text { laboratories of corporations }\end{array}$ \\
\hline 8 & $\begin{array}{l}\text { Nanotechnologies, } \\
\text { neurotechnologies, IT-technologies, } \\
\text { resource-saving technologies, etc.; } \\
\text { the eighth technological order, } \\
2010-2040 ;\end{array}$ & $\begin{array}{l}\text { States, } \\
\text { trade and economic blocks, } \\
\text { virtual blocks of states, } \\
\text { multipolar world, } \\
\text { UN }\end{array}$ & $\begin{array}{l}\text { Research and education in } \\
\text { technology platforms and } \\
\text { clusters, development of } \\
\text { project and smart education }\end{array}$ \\
\hline
\end{tabular}

Source: developed by the author 
TABLE 2: Analysis of the process of transformation of socio-economic institutions during the change of technological orders (ending)

\begin{tabular}{|c|c|c|c|}
\hline $\begin{array}{c}\text { № } \\
\text { П/ா }\end{array}$ & $\begin{array}{l}\text { Institutes of technological structure } \\
\text { Name, number, time period of } \\
\text { technological structure }\end{array}$ & $\begin{array}{l}\text { Social system, } \\
\text { human rights, } \\
\text { the elite of society }\end{array}$ & $\begin{array}{c}\text { Organizational structures of } \\
\text { business, } \\
\text { Concepts of organization } \\
\text { management, } \\
\text { work with personnel } \\
\end{array}$ \\
\hline (1) & (2) & (5) & (6) \\
\hline 1 & $\begin{array}{l}\text { Horse traction; "1" (the first) } \\
\text { Technological order (way), } \\
2000 \text { BC. - IX century AD; }\end{array}$ & $\begin{array}{c}\text { community-tribal, } \\
\text { natural human rights, the elite } \\
\text { is elected by the clan; } \\
\text { slaveholding, } \\
\text { slavery, elite-slaveholders }\end{array}$ & $\begin{array}{l}\text { Traditional organizational } \\
\text { structures, } \\
\text { Centralization, organization, } \\
\text { control, labor stimulation, }\end{array}$ \\
\hline 2 & $\begin{array}{l}\text { Windmill, a water mill; } \\
\text { "2nd" technological order, } \\
\text { IX century-1770; }\end{array}$ & $\begin{array}{l}\text { Feudalism, } \\
\text { Limited human rights, the } \\
\text { elite-the Prince and his squad }\end{array}$ & $\begin{array}{l}\text { Traditional organizational } \\
\text { structures, } \\
\text { Definition of requirements for } \\
\text { the manager, the theory of } \\
\text { power, the study of the impact } \\
\text { of automation }\end{array}$ \\
\hline 3 & $\begin{array}{l}\text { Textile machines, the } \\
\text { third technological order, } \\
\text { 1770-1830; }\end{array}$ & $\begin{array}{l}\text { Capitalism, recognition of the } \\
\text { right of a person to dispose of } \\
\text { his labor force; elite } \\
\text { monarchs, feudal lords, } \\
\text { capitalists }\end{array}$ & $\begin{array}{c}\text { Traditional organizational } \\
\text { structures Economic theory, } \\
\text { finance theory, the principle of } \\
\text { labor specialization }\end{array}$ \\
\hline 4 & $\begin{array}{l}\text { Steam engine, the } \\
\text { fourth technological mode, } \\
\text { 1830-1880; }\end{array}$ & $\begin{array}{l}\text { Capitalism, recognition of the } \\
\text { right of a person to dispose of } \\
\text { his labor force; elite } \\
\text { monarchs, feudal lords, } \\
\text { capitalists }\end{array}$ & $\begin{array}{c}\text { Traditional organizational } \\
\text { structures, theory of public } \\
\text { services, analysis of employee } \\
\text { motivation }\end{array}$ \\
\hline 5 & $\begin{array}{l}\text { Internal combustion engine and } \\
\text { electric motor; } \\
\text { the fifth technological order, } \\
1880-1930\end{array}$ & $\begin{array}{l}\text { Capitalism, recognition of the } \\
\text { right of a person to dispose of } \\
\text { his labor force; elite } \\
\text { hereditary capitalists }\end{array}$ & $\begin{array}{l}\text { Functional organizational } \\
\text { structures, scientific } \\
\text { management, methods of } \\
\text { statistics in management, } \\
\text { personnel work }\end{array}$ \\
\hline 6 & $\begin{array}{l}\text { Electronic computer, genetics; } \\
\text { the sixth technological order, } \\
1930-1970\end{array}$ & $\begin{array}{l}\text { Capitalism, the Universal } \\
\text { Declaration of Human Rights; } \\
\text { the elite hereditary } \\
\text { capitalists, the sexual } \\
\text { revolution }\end{array}$ & $\begin{array}{l}\text { Product organizational } \\
\text { structures, Operational } \\
\text { research, system analysis, } \\
\text { marketing, personnel } \\
\text { management, }\end{array}$ \\
\hline 7 & $\begin{array}{c}\text { Microelectronics, } \\
\text { The seventh technological order, } \\
\text { 1970-2010; }\end{array}$ & $\begin{array}{l}\text { Capitalism, the Universal } \\
\text { Declaration of Human Rights; } \\
\text { elite capitalists who have } \\
\text { made their own fortune }\end{array}$ & $\begin{array}{c}\text { clusters, technology platforms; } \\
\text { participatory management, } \\
\text { human resource management }\end{array}$ \\
\hline 8 & $\begin{array}{c}\text { Nanotechnologies, } \\
\text { neurotechnologies, } \\
\text { IT-technologies, } \\
\text { Resource -saving technologies, etc.; } \\
\text { the eighth technological order, } \\
\text { 2010-2040; }\end{array}$ & $\begin{array}{l}\text { Capitalism, recognition of the } \\
\text { rights of minorities; elite } \\
\text { capitalists from the field of } \\
\text { information technology }\end{array}$ & $\begin{array}{c}\text { Organizational architecture, } \\
\text { design, culture; } \\
\text { neuromanagement, } \\
\text { neuromarketing, management } \\
\text { of social development of } \\
\text { personnel }\end{array}$ \\
\hline
\end{tabular}

Source: developed by the author 
In this article, the institute of a new (eighth) technological order will be understood as a system of social and professional relations in certain areas of activity. A special feature of these socio-professional relations is that they are closely related to the specifics of the technologies of innovation and/or production activities of the organization.

As you know, technologies are called system integration: methods of production; means of production; qualification skills of personnel. The technologies of work are closely related to the organizational culture of the type of activity.

The process of developing new socio-industrial institutions can be divided into two directions.

The first direction of the development of institutions of the eighth (sixth) technological order includes the development of relations that allow creating new technologies: nanotechnologies, neurotechnologies, information technologies, digitalization technologies, resource-saving technologies.

The second direction of the development of institutions of the eighth (sixth) technological order is associated with the creation of systems of relations aimed at aggregation (system integration) and multiplication (repeated application, introduction) of new technologies into products and production systems of previous technological orders.

The structure of a socio-professional institute of a new technological order (way) is a set of elements of such an institute and the connections between them. The structure of the socio-professional institute of a new technological way can include relations: firstly, based on verbal communications and explicit knowledge (explicit relations), and secondly, relations based on non-verbal communications and implicit knowledge (implicit relations).

At the same time, verbal and non-verbal relationships can be divided into the following types of relationships:

- technologically determined relations determined by the specifics of relations within certain technologies of a new technological order. These relationships can become business customs;

- integration relations related to the need to introduce new technologies into the production processes of previous technological orders (structures);

- cultural relations based on the mission, vision, values of a certain direction of technological and/or integration development within the framework of a new technological order, and more.

- In the future, in this paper, we will proceed from the fact that there is such a logical connection:

- the development of new technologies of a new technological order and their introduction into the real economy requires new types of socio-professional relations (institutions);

- in turn, the development of new institutions is based on the formation of a new mentality of employees (or the selection of employees with a certain mentality);

- the new mentality of employees may enter into a mental conflict with the institutions (and the mentality of employees) of previous technological orders.

At the same time, at the beginning of the formation of a new technological order, the old institutions are always in the majority and are stronger in the organizational aspect.
Is the defeat of the new institutions (and mentality) predetermined? No. In life, professional conservatism is opposed by mentoring in relation to innovatively active individuals. The institute of mentoring is active in developed countries.

The mentor protects the sprouts of a new technological order. The mentor's motives can be: material (if we are talking about business angels) or non-material (if we are talking about charitable foundations).

For example, as everyone knows, an important official in Russia, Ivan Ivanovich Shuvalov, selflessly supported Mikhail Lomonosov. This helped M. Lomonosov to create science in Russia, to open the Moscow University and more.

The lack of mentoring slows down scientific and technological progress and the formation of a new technological order.

The concept of mentality is not universally recognized. For example, they believe that the mentality (from the Latin "way of thinking") represents those spiritual, moral and cultural values that form the basis of a person's worldview and worldview.

Therefore, in this article, we will understand the following by the mentality. Mentality is a system association of: a mindset; the level of abstraction of thinking; ways of thinking; mindset; perception of the surrounding world; culture of thinking processes; culture of communication, and more. The mentality determines the propensity for a certain professional activity and a certain type of organizational behavior. We can talk about the mental basis of socio-professional institutions. Differences in people's mentalities lead to a contradiction of their interests and behavior. This can create a conflict situation in the organization. Such a conflict situation may occur between institutions (and people) from previous technological structures and institutions of a new technological order.

The human mentality has a complex structure. It is possible to distinguish: professional mentality; social mentality; cultural mentality of a person and others.

The main functions of the mentality can be called:

1) establishing the existence of differences in the way of thinking of various professional groups of employees;

2) descriptions of the way of thinking and perception of the world by representatives of various professional groups; (for example, employees can be divided into theorists and practitioners);

3) positioning employees with different types of mentality in relation to their place and role in the organization;

4) the function of mental multiplication, in which the manager selects subordinates close to the mentality;

5) a protective function, which consists in the fact that people with a different mentality can be forced out of the organization and more.

The roles of the mentality can be called: the division of employees on a mental basis into "your own (friends)" and "someone else's (strangers)"; improving the effectiveness of interpersonal communications between mentally close employees; determining the type of organizational behavior of an employee, and more. 
A conflict situation in an organization can be "functional" if it allows you to increase the effectiveness of the organization's activities. A conflict is recognized as "dysfunctional" when it leads to a decrease in: the effectiveness of the organization's work, personal satisfaction, group cooperation and other negative effects. For a firm, the role of a conflict is determined by the extent to which this conflict is effectively managed [20, pp. 367372]. Consequently, in management recognizes the ability of conflict to accelerate and / or slow down the processes of innovative development in large technological systems (a technological order).

Further improvement of the classification and research of the features of conflicts is necessary to reduce the damage from conflicts, to successfully manage conflicts.

The current crisis associated with the development of a new technological order can be a source of various kinds of explicit or latent, more or less acute conflicts.

In the interests of reducing the damage from conflicts by:

First, increasing the level of functionality (a positive result of the conflict);

Secondly, to reduce the level of dysfunctionality (negative results of the conflict), it is important to understand the direction, meaning and content of the changes in socioeconomic relations (institutions) taking place in 2021 during the development of a new technological order.

The positive role of mental conflicts can be realized only when, as a result of the conflict, a new mentality and the development of institutions of a new technological way will receive support.

Otherwise (the mentality of the new technological order has not received support), there is a negative role of mental conflict. This negative role of mental conflict consists in inhibiting the development of institutions of a new technological order. Additionally, damage may be caused to: the national economy; personal careers (image, income, etc.) of innovatively active employees.

- In the process of formation of institutions of a new technological order, the cause of conflict situations may be:

- creation of new theories, technologies, products and productions in the process of innovation activity;

- competition for limited investment resources and income between "old" and " new " goods, areas of development, services, production technologies;

- changes in key developments (research and development works), the emergence of fundamentally new objects of scientific research, objects of priority investments in new production and technologies;

- transformation of the assessment of the importance and results of innovative activities of research institutes, organizations and / or individuals in connection with the development of new technologies;

- an increased monetary innovation multiplier of new technologies [23, pp. 77-88]. Let's explain the essence of the monetary innovation multiplier by an example. An automobile engine costs about 30 times more than the weight of aluminum;

- reduction of profitability of businesses (enterprises) of previous technological structures against the background of the development of new technologies;

\section{psychological alarmism of individual managers.}

- Psychological alarmism of an employee manifests itself as a feeling of a threat to reduce his scientific and / or socio-economic status.

Let's give an example. In the period of the fifth (third [28; 29 , p. 3-29; 26, p. 30-38]) technological order (structure), electric locomotives were new products. The profession of an electric locomotive driver was prestigious and the most highly paid. During the period of the sixth (fourth) technological order, the most advanced technical product was aircraft (aircraft were produced by 7 countries). The competition of applicants to aviation universities was the maximum. The most prestigious and profitable profession has become the profession of a pilot. At the same time, the social status, the prestige of the profession of an electric locomotive driver has decreased, etc.

In the period of the sixth (fourth) technological order, computers became a new product. The profession of a programmer is becoming popular.

In this article, the monitoring of conflicts in the process of developing institutions of a new technological order allowed us to identify a new type of conflict, namely, mental conflicts.

In this article, it is proposed to define a mental conflict as such a conflict, the cause of which is different ways of human mental activity, different assessment of the process of development of new institutions in the economy and society by the parties to the conflict.

Philosophical and scientific disputes on such problems as: is the Earth round or is it flat and stands on three whales; does the Earth revolve around the Sun or, conversely, does the Sun revolve around the Earth?; are cybernetics and genetics pseudosciences or should they still be recognized as the most real sciences, etc.

The mental conflict in the USSR Academy of Sciences is historically known and described in a number of works [12, p.82-95; 13, p. 3-14; 14, p. 82-83; 15; 16, p. 108-121]. As a result of this conflict, the development of computer technologies and genetics has slowed down. Therefore, there was a decrease in the competitiveness of the industry.

One of the characteristic features of such conflicts can be considered explicit or latent (hidden) psychological alarmism. Such alarmism is associated with a person's dissatisfaction with the trends of socio-economic transformations in the development of scientific and technological progress. At present, we can talk about alarmism in relation to the development of a new technological order. As a rule, the initiator of a mental conflict is actually an alarmist-minded party.

In psychology, alarmism is considered a panicked or anxious emotional state of a person. This state is determined by the negative reaction (of a person or group of persons) to the current state of affairs and prospects in the future. In this case, the psychological alarmism regarding the formation of a new technological order of life can be anxiety, determined by the following: the possibility of reducing the social significance and payment for work in their profession in connection with the formation of new institutions and research and development work in the interests of new technologies; the probability of nominating new persons with a different mentality to the leadership of a research institute, design bureau or university from among employees conducting research in the field of products and production facilities of a new technological order; 
the appearance of a feeling, perception of a real or imaginary threat to their professional position; a potential threat coming from the mentality and/or obtained new scientific and/or innovative results of developers of a strategy for the development of a new technological order (way), and more.

The specifics of the course of such a conflict may be as follows.

(1) The leader of a new scientific or technological direction is under attack. The one who attacks, as a rule, is engaged in activities that are part of the previous technological orders. In this situation, the parties to the mental conflict can be subjects who carry out activities characteristic of the previous technological orders (structures). Probably, specialists in the field of track and track management (4th technological order) or manufacturers of electric locomotives (5th technological orders) may not understand the meaning of activities in the field of neurotechnologies, neuromarketing in transport within the eighth technological orders, etc. [24, pp. 201-212]? Presumably, this is true, based on the fact that departments and laboratories of neurotechnologies have not yet been created in transport universities?

(2) Both sides of the mental conflict carry out their developments in the field of a new technological way, but at the same time these parties to the conflict differently assess the significance and/or impact of their projects for the development of a new way and its elements, and others.

In the process of mental conflict, one subject seeks to create obstacles in the work of the other party. This can be done by: not extending the contract; banning certain works; banning publications on certain topics; by refusing to print articles in journals; silencing works and other methods.

At the same time, if the psychological alarmism of one of the subjects has a hidden (latent) character, then this subject can camouflage the cause of the conflict under other types of conflict. For example, this subject may, as an official reason, put forward reasons that are not directly related to the essence of the conflict, in particular, try to accuse of allegedly violating ethics in the complete absence of any reasons for this.

An important feature of this type of mental conflict may be the violation of rights and freedoms when performing scientific research.

At the same time, it is important to remember that the Universal Declaration of Human Rights has established (Article 27) that everyone has the right to protect his material and moral interests, which are the result of his scientific, literary or artistic works, etc.

A fundamentally important event and an argument in favor of defining mental conflicts as a separate type of conflict can be the official recognition of the fact that a new type of thinking has appeared in people in the 21st century. We are talking about the development of "clip thinking" in the post-millennial generation. This type of thinking is characterized by the fact that its carriers perceive the surrounding world as a series of unrelated "pictures". At the same time, the logical component of the thinking process in people with this type of thinking is weakened [25, p. 109-111].

The formation of subjects of financial and economic activity with such thinking, the growth of the number of such subjects increase the risk of mental conflicts during the development of a new technological order.
The possibility of mental conflicts increases during the competitions of scientific and pedagogical workers of universities. This is due to the procedure of evaluation, recognition or non-recognition by the competition commissions of the achievements of applicants for the position. Therefore, it can be recommended to take into account the probability of a mental conflict during the competitive selection (competition) of scientific and pedagogical staff of universities.

At the same time, competitions can be an important tool for the development of institutions of a new technological order.

We will call the competition of potential employees (applicants) for the right to conclude a contract to work at this university a competition of scientific and pedagogical workers of universities. For the correct conduct of the competition, a number of requirements must be met: all employees of the university and external applicants must be on equal terms; the costs of applicants for participation in the competition must be minimal; the criteria for selecting the winners of the competition must be described; the organization and summing up of the results of the competition must meet the requirements (principles) of the legislation (integrity, reasonableness, fairness) and others.

The functions of the competition of university employees can be called:

(1) formation of a socio-professional institute of a new technological order (structure), taking into account basic technologies by selecting the most productive employees of the university;

(2) the function of assessing the development trend of the university staff (for example, if it turns out that the bulk of the applicants ' work is not devoted to the new technological order, then there is a slowdown in development);

(3) the function of motivating employees to work more productively on the development of new technological institutions, and more.

The competition of scientific and pedagogical staff of the university plays the role of a tool for the development of institutions of a new technological order:

- if, as a result of the competition, employees working in the field of development of a new technological order (way) are selected for the organization, then such competitions have a positive effect and contribute to the development of institutions of this new way;

- if employees working in the interests of the development of a new technological order are dismissed from the organization using contests, then such contests have a negative role (and effect).

This negative role consists in inhibiting the development of a new technological orders in the economy and causing personal (career, image, material damage, damage to life and health, etc.) innovatively active employees of this organization. At the same time, it should be taken into account that such an organization and its employees are part of the national economy. The slowdown in the development of one organization leads to a slowdown in the economy as a whole.

It is easy to determine exactly what role, for example, competitions of university employees play by qualitative analysis of publications of university employees during 
the competition. Such an objective comparative analysis of the direction of research of managers and employees of the university can immediately allow us to establish the personnel priorities of the administration of this scientific and / or educational institution? In addition, in this way, information can be obtained about which psychological moods (the psychology of innovation activity or psychological alarmism) are prevalent in this organization)?

It can be recommended to take into account not only how many and what publications the applicant has, but also to give a qualitative assessment of all publications. In particular, it is important to assess the technological order of the knowledge of the commission members and the candidate for the position. If the candidate works in the field of development of a new technological way, and at the same time the member of the competition commission himself works in the field, for example, of the previous technological order, then it will probably be difficult for such members of the commission to adequately assess the achievements of the applicant for the position?

It is proposed to recognize that the integral assessment of the correctness of the work of the competition commission of the university can only be the result of its activities: if after the competition the number and quality of works in the field of development of a new way of life increases, then the competition commission works for the development of a new technological order (works effectively)?

In addition, it is necessary to take into account the level of the hierarchy of the technological pyramid to which the knowledge and organizational culture of the members of the competition commission and/or the applicant belong. As you know, there is a five-level technological pyramid within all technological orders. At the first (highest) level of this pyramid, there are firms that develop technological concepts of principles. At the next (second) level of this pyramid, technology developers are located. At the third level of this pyramid, developers and manufacturers of technical means, for example, aircraft, are placed. At the fourth level of the pyramid under consideration, operating organizations (for example, air carriers) are located. At the fifth (lowest) level of the hierarchy in this technological pyramid, organizations working in agriculture or in the field of extraction of raw materials are located. It should be taken into account that each of these activities has its own profitability. At the same time, each of these activities has its own special mentality, values and organizational culture. Therefore, representatives of operating organizations (the fourth level) may not understand the developers of conceptual approaches (the first level of the hierarchy).

Due to the circumstances listed above, as well as due to differences in experience and/or the specifics of the work of the subjects, a mental risk may manifest itself. This risk consists in an incorrect (in the opinion of the other party) assessment of the significance and/or indicators of the work performed and/or the existing achievements of the candidate. Note that such a risk is higher for a researcher working in a more high-tech segment of concepts and technologies of a new technological order. This can be a source of mental conflicts.

Mental conflict can also have a number of interpretations. In particular, the materials of this article allow us to call the opposition of one side to the interests of the other side a mental conflict. This opposition may have the following grounds: misunderstanding of one of the parties to the conflict of the way and features of thinking of the other party; due to the fact that the activities of the parties relate to different technological orders, there may be a misunderstanding of the architecture and / or design of the thinking process of another subject; misunderstanding of people with clip and logical thinking by each other; misunderstanding of the intellectual and cultural parts of the activity at various hierarchical levels of the technological pyramid, located within this technological order and other reasons.

A mental conflict can also affect the field of culture, such a conflict can be aggravated for reasons of discrepancies between different professional cultures and values. At the same time, it should be taken into account that different professions, activities within different technological orders, etc. are inherent in specific professional values and types of cultures (baseball team, academic, etc.). For example, observations show that specialists in the manufacture of vehicles in transport engineering may not understand the importance of forming a general scientific theory of transport systems or the importance of the development of neurotechnologies in transport and transport engineering?

\section{DISCUSSION}

As the materials of this article show, the causes of mental conflicts are quite numerous. Such conflicts can occur not only between people with logical and clip thinking. The reason for the conflict may also be a different level of abstractness of human thinking. For example, there may be a mental conflict between members of the same team (team) for testing mechanical engineering products due to the fact that one employee likes to perform checks and setup of a prototype product more, and another employee is more suitable for processing and analyzing test results. Presumably, such preferences of the test team employees are explained by the level of abstract thinking? Often such conflicts are mistaken for sensual interpersonal conflicts.

In management, a mental conflict can be attributed to the conflict between the contours of strategic and operational management?

The situation is approximately the same in the scientific world: some scientists prefer to process statistics of real processes at enterprises, while other scientists are more interested in dealing with conceptual aspects of activities and developments.

The development of a new technological order needs further development of the methodology of a number of scientific areas (theory of complex systems, system analysis, etc.). The struggle of opinions, the defense of scientific priorities-all this can be the cause of a mental conflict in the process of developing new technological order (way).

Probably, the most frequent source and moment of the emergence of mental conflict in science can be the process of generating a new scientific direction in the course of the development of a new technological order? Perhaps this kind of mental conflict can be called a kind of conflict of "technological civilizations"? With this approach, the eighth (sixth) technological order should be perceived as a new technological, socio-economic and cultural civilization at the same time. It is predicted that the formation of new intellectual and information technologies will lead to even more large-scale changes in human thinking and culture. All this will serve as an additional source of mental conflicts.

Therefore, there is reason to assert that the role of mental conflicts will increase during the development of a new technological order. 
In the course of the development of a new technological order, it is possible to further increase the intensity of mental conflicts between developers of new technologies and products within this way and the personnel of organizations working in the technology segment of previous technological orders.

Timely identification, description, diagnosis and resolution of such conflicts can reduce the amount of damage from such conflicts, accelerate the development of a new technological order in society and the economy.

At the same time, it is necessary to take into account the risk of incorrect identification of this kind of conflicts, for example, for reasons of hiding the causes and/or manipulating the causes of the conflict. In addition, as already noted, it is quite difficult to distinguish such conflicts from the sensory conflicts already studied in management [21, p.172 -177].

For a more accurate diagnosis of mental conflicts, it can be recommended to conduct additional comparative studies in order to get an answer to such questions: does the activity of the subjects of the conflict belong to different technological orders?; does the activity, the field of scientific interests of the subjects belong to different levels of the hierarchy of the technological pyramid?; the evaluation of which works of the candidate gave rise to this conflict, and more?

As already noted, it is necessary to take into account the fact that the psychological support and the reason for participating in such a conflict is alarmism, and the fear of one of the parties before scientific and technological progress characteristic of it. This fear generates the stress of the conflict participant and his desire to reduce the effectiveness of the activities of the other side, which contributes to the scientific and technological progress of the economy and society with its scientific achievements and innovations.

When assessing the ethical behavior of subjects of this type of conflict, it is necessary to take into account that the target institutional task of science and education is precisely to accelerate and support the progress of the economy and society during the formation of a new technological order.

Presumably, the state authorities of science and education, public organizations in this field should take measures to timely detect, diagnose, and minimize damage from this type of conflict.

This is due to the fact that the successful detection and reduction of the risk of mental conflicts will increase the pace of scientific and technological progress of the state and society. A low level of mental conflicts can increase the attractiveness and competitiveness of the national innovation system and universities. Universities should be able to identify and resolve this type of mental conflicts.

In conclusion of this article, we will present some of the issues inherent in the process of formation of a new technological order. These questions can give rise to mental conflicts:

(1) should the development of a new technological order proceed spontaneously or should this process be managed?

(2) what methods and tools should be used to manage the development of a new technological order in the economy and society?
(3) is it necessary to apply strategic planning for the development of a new technological order and, if "yes", at what levels [26, p. 30-38]?

(4) the theory of technological orders: is this part of economic theory or does it relate to the theory of large systems?

(5) world university rankings: a field of competition in publications or a tool for improving the competitiveness of education?

(6) do modern technical universities need humanities faculties (law, economics, sociology, etc.)?

(7) is it necessary to develop the theory of project-based higher education or is it a purely practical area of activity of universities?

(8) how many technological structures should be allocated: eight or six, or another number?

There may be other sources of mental conflicts.

\section{CONCLUSION}

The article discusses the mechanism of development of social and professional relations (institutions) in the process of formation of a new technological order, describes the structure of such institutions. The article shows that the tools for the development of new institutions can be: mental conflicts; mentoring; competitions of researchers; methods of conflict management and more. It is proved that all social and professional institutions have their own special mental basis. The functions of mental conflicts and contests are described. It is shown that during the development of a new technological order, the probability of mental conflicts increases. It is proved that mental conflicts can be considered as a new type of conflicts. The arguments are given in favor of the fact that the damage from this type of conflict can lead to a slowdown in the socio-economic progress of the university, industry, and country. To reduce the risks and damages from this type of conflict, it is necessary to investigate and describe their essence. The factors that distinguish mental conflicts from conflicts of other types are described. It is noted that one of the probable causes of mental conflicts may be the formation of a clip type of thinking in people born after 2000. It is proved that in the interests of reducing the damage from mental conflicts, it is necessary for the management of firms, corporations, universities to detect, diagnose and resolve mental conflicts in a timely manner.

\section{REFERENCE}

[1] Ismailov B. I. Managing the dynamics of a complex system//Eurasian Union of Scientists. 2019. No. 12-5 (69). pp. 6-11.

[2] Muntyan E. R. Implementation of a fuzzy model of interaction of objects of complex technical systems based on graphs//Software products and systems. 2019. No. 3. pp. 411-418.

[3] Yemelyanova Yu. G., Fralenko V. P. Methods of cognitivegraphical representation of information for effective monitoring of complex technical systems//Software systems: theory and applications. 2018. Vol. 9. No. 4 (39). pp. 117-158.

[4] Cherkasova T. P., Melikhova B. S., Mishurina O. V. Opportunities and problems of the innovative type of economic growth in Russia: institutional approach//Science and education: economy and economics; entrepreneurship; law and management. 2017. No. 10 (89). pp. 130-133. 
[5] Malikov R. I., Grishin K. E. Methodological approaches to modeling the parameters of a favorable institutional configuration of the regional business environment//In the collection: Science today: theory and practice. collection of scientific papers of the II International Correspondence scientific and practical Conference. 2016. pp. 126-132.

[6] Shvets I. Y. Institutional aspects of the national innovation system//Drucker's Bulletin. 2019. No. 5 (31). pp. 5-18.

[7] Glushchenko V. V. Kriszologiya: the general theory of the crisis, the image of the post-crisis future, the criterion approach to research and the risk theory of the firm, the paradigm of intelligent risk management. - M: IP Glushchenko Valery Vladimirovich, 2011. - 80 P.

[8] Sergeev V. M., Kazantsev A. A., Medvedeva S. M. Territorial heterogeneity of globalization and the types of conflicts generated by it//The policy. Political research. 2020. No. 1. pp. 44-61.

[9] Karbanova A. N. Overcoming social and labor conflicts at the enterprise during the crisis//In the collection: Issues of management and economics: the current state of actual problems. Collection of articles based on the materials of the IX International scientific and practical conference. 2018. pp. 51-58.

[10] V Glushchenko. V. Socio-economic transformations and mental conflicts during the development of the sixth technological order//Kazakhstan scientific journal. 2021. Vol. 4. No. 6 (31). pp. 12-26.

https://sciencejournal.press/sj/article/view/262/21 3 (accessed: 30.06 .2021 ).

[11] In Glushchenko.V. Competitive selection of scientific and pedagogical staff of the university as a scientific and legal category//Kazakhstan scientific journal. 2021. Vol. 4. No. 6 (31). pp. 27-40.

https://sciencejournal.press/sj/article/view/260/21 2 (accessed: 25.06.2021)

[12] Dragavtsev V. A. Nikolay Ivanovich Vavilov - one of the great scientists of the earth in the field of plant genetic resources//News of the Timiryazev Agricultural Academy. 2012. No. 4. pp. 82-95.

[13] Kolchinsky E. I. N. I. Vavilov And T. D. Lysenko in the space of historical and scientific discussions//Nature. 2018. No. 1 (1229). pp. 3-14.

[14] Fischer R. E. What kind of person is Lysenko? //Samara Luka: problems of regional and global ecology. 2020. Vol. 29. No. 1. pp. 82-83.

[15] Yablonsky L. T. "Lysenkoism" in modern American anthropology and genetics//Article in the open archive No. 7182 16.02.2016

[16] Vasiliev N. N. The phenomenon and fate of cybernetics in the context of the history of the Soviet intelligentsia of the second half of the twentieth century//Intelligentsia and the world. 2012. No. 4. pp. 108-121.
[17] Zarubina N. N. Problems of pseudoscience in Russia: risks of demarcation of various forms of knowledge//Search: Politics. Social studies. Art. Sociology. Culture. 2017. No. 6 (65). pp. 113-123.

[18] Myslivchenko V. A. Science and the role of"big ideologies". Some aspects//In the collection: Actual problems of modern science in the 21st century. collection of materials of the XV International Scientific and Practical Conference. 2017. pp. 50-53.

[19] Pavlov R. N. Age qualification as a factor of reducing the quality of scientific research//In the collection: Russia: trends and prospects of development. Yearbook. INION RAN. Moscow, 2015. pp. 550-553.

[20] Mexon M. H., Albert M., Khedouri F. Fundamentals of management: Trans. from English-M.: "Delo", 1993703s.

[21] Glushchenko V. V., Management: system foundations - G. Zheleznodorozhny M. O., LLP SPC "Wings", 1998, ed. 2-e. -224 p.

[22] Glushchenko V. V., The theory of technological structures. - M.: Glushchenko Valery Vladimirovich, 2020. - 80 p.

[23] Glushchenko V. V., Glushchenko I. I. The essence of the monetary innovation multiplier in the economy / / Bulletin of Science and Practice. 2016. No. 3. pp. 77-88. [Electronic resource].

[24] Glushchenko V. V., Glushchenko I. I., Plakhotin E. O., Shinaeva A. I. Managerial neuromarketing in the sphere of services on railway transport [Electronic resource] / / Youth Scientific Bulletin. 2017. No. 11(24), pp. 201-212. URL:(http://www.mnvnauka.ru/2017/11/Glushchenk o.pdf (17 17.11.2017).

[25] Howe, Neil; Strauss, William. Millennials and K-12 Schools (neopr.). - Life Cycle Partners-2008. - pp. 109111. - ISBN 0971260656

[26] Glushchenko V. V. (2021). Strategic planning of the transition of organizations to the sixth technological order in the national economy// International Journal of Engineering Scientific Technologies, 5(1), 30-38. https://doi.org/10.29121/ijoest.v5.i1.2021.159

[27] Glushchenko V. V. The paradigm of intellectual management of the formation of the sixth technological order in the economy / / Scientific Heritage, 2020, vol. 4, No. 45 (2020), pp. 54-63.

[28] Aivazov A. (2012). The periodic system of world capitalist development. [Electronic resource] Access mode: http://ajvazov.ru/articles/periodicheskaya-sistemamirovogo-kapitalisticheskogo-razvitiya. html, free. Title from the screen. Yaz. rus. (accessed December 2015).

[29] Glazyev S. Yu. World economic patterns in global economic development//Economics and mathematical methods. 2016. Vol. 52. No. 2. pp. 3-29. 